\title{
FIRST TAIWANESE AND NORTHERNMOST RECORDS OF PLECTORHINCHUS POLYTAENIA (ACTINOPTERYGII: PERCIFORMES: HAEMULIDAE)
}

\author{
Keita $\mathrm{KOEDA}^{1^{*}}$ and Hsuan-Ching $\mathrm{HO}^{1,2}$ \\ ${ }^{1}$ National Museum of Marine Biology \& Aquarium, Checheng, Pingtung, Taiwan \\ ${ }^{2}$ Institute of Marine Biology, National Dong Hwa University, Pingtung, Taiwan
}

Koeda K., Ho H.-C. 2018. First Taiwanese and northernmost records of Plectorhinchus polytaenia (Actinopterygii: Perciformes: Haemulidae). Acta Ichthyol. Piscat. 48 (3): 245-249.

\begin{abstract}
Twelve species of the genus Plectorhinchus have been recorded from Taiwanese waters. Although Plectorhinchus polytaenia (Bleeker, 1853) is known from Indo-West Pacific north to Philippines, it has not previously been reported from Taiwan. The main objective of this paper is to document the presence of this species in the waters of Taiwan. Three specimens (212.6-344.3 mm standard length) of $P$. polytaenia were collected from southern Taiwan in 2017. The morphology and fresh coloration of the collected specimens are herein described. The majority of the morphological characters agree well with previous descriptions of $P$. polytaenia: chin naked with 6 pores; total gill rakers 27-28; dorsal fin with 12-13 spines and 21-22 rays; scales ctenoid; lateral line scales 54-56; 8-11 black-edged white longitudinal stripes on body; fins, iris and upper lip yellow; tongue and gill rakers scarlet. Therefore, the specimens from southern Taiwan are identified as Plectorhinchus polytaenia. The presently described specimens represent the first record for Taiwan, as well as the northernmost record of this species.
\end{abstract}

Keywords: taxonomy, distribution, coral reef, sweetlips, Plectorhinchus lineatus

\section{INTRODUCTION}

The genus Plectorhinchus Lacepède, 1801, family Haemulidae, is characterized by chin naked with 6 sensory pores, more than 11 spines and fewer than 22 soft rays on dorsal fin, 10-17 scales between lateral line and dorsal-fin origin (McKay 2001). Twelve species of the genus have been recorded from Taiwanese waters (Shen and $\mathrm{Wu} 2011)$.

During market samplings at Hengchun fish market in 2017, three specimens of Plectorhinchus polytaenia (Bleeker, 1853) (Fig. 1) fished off Kenting at southern Taiwan were collected. The species was previously recorded from western Pacific north to Philippines, thus the specimens represent the first Taiwanese record and the northernmost record of the species. The morphology and fresh coloration of the newly collected specimen are described herein.

\section{MATERIALS AND METHODS}

Counts and measurements follow Satapoomin and Randall (2000). Measurements were made to the nearest $0.1 \mathrm{~mm}$ with needle-point callipers. Standard and head lengths are abbreviated as SL and HL, respectively. The morphological description is based on the specimens collected from Taiwan. The specimens of the genus Plectorhinchus examined in this study are deposited at the
Kagoshima University Museum (KAUM) and National Museum of Marine Biology \& Aquarium (NMMB-P).

Specimens examined. NMMB-P26732, $283.1 \mathrm{~mm}$ SL, NMMB-P26733, $212.6 \mathrm{~mm}$ SL, collected from off Kenting, Pingtung, southern Taiwan, purchased by the first author at Hengchun market in 1 September 2017; NMMB-P27296, $344.3 \mathrm{~mm} \mathrm{SL}$, same as other two specimens, 17 November 2017.

Comparative materials. Plectorhinchus lineatus: KAUM-I. 82708, $446.0 \mathrm{~mm}$ SL, Tanega-shima Island, Japan; P. vittatus, KAUM-I. 30167, 273.5 mm SL, Uchinoura Bay, Kagoshima, Japan.

\section{RESULTS}

\author{
Family HAEMULIDAE \\ Plectorhinchus Lacepède, 1801 \\ Plectorhinchus polytaenia (Bleeker, 1853) \\ 色帯胡椒鯛 (New Taiwanese name) \\ Fig. 1
}

Plectorhinchus polytaenia (Bleeker, 1853): 755 (type locality: Sulawesi, Indonesia). Randall et al. 2000: 619; McKay 2001: 2980; Allen and Erdmann 2012: 477; Larson et al. 2013: 138.

Description of Taiwanese specimens. Counts and measurements are shown in Table 1. Body oblong and 


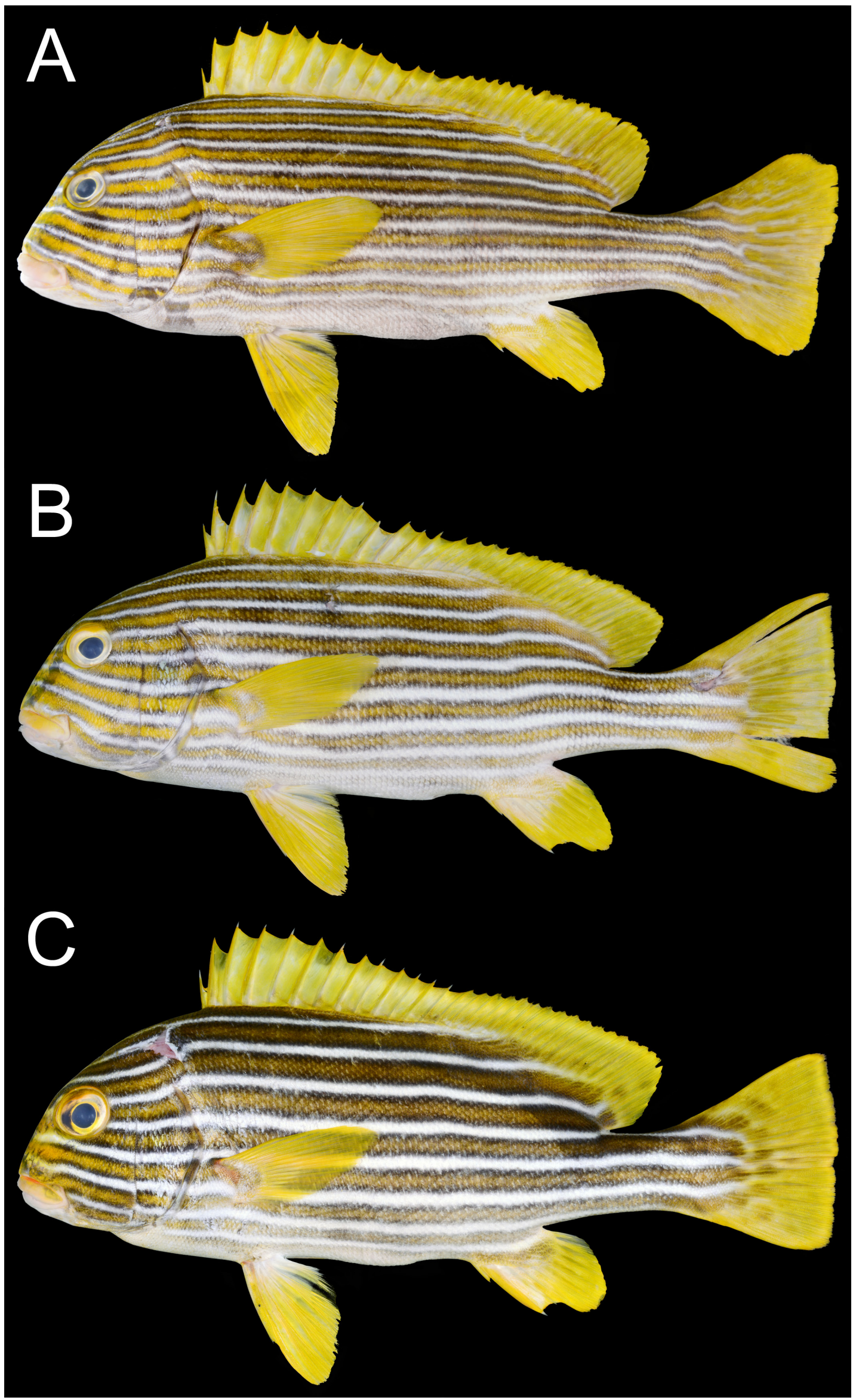

Fig. 1. Fresh specimens of Plectorhinchus polytaenia from Kenting, southern Taiwan. A: NMMB-P 27296, $344.3 \mathrm{~mm}$ SL standard length (SL); B: NMMB-P 26732, 283.1 mm SL; C: NMMB-P 26733, 212.6 mm SL 
compressed, greatest depth at origin of dorsal fin, greatest width at uppermost point of pectoral-fin insertion; dorsal profile rising straight from snout to anterior of eye, slightly bent horizontal to dorsal-fin origin, thereafter lowering to caudal peduncle; ventral profile slightly lowering from lower-jaw tip to origin of pectoral fin, thereafter rising from anal-fin origin to caudal peduncle. Caudal peduncle well compressed.

Body covered with small rough ctenoid scales. Snout and lips without scales. Lateral-line continuous, parallel with dorsal contour. Eye and iris rounded. Interorbital space slightly convex. Posterior edge of preopercle serrated. Lower edge of preopercle and opercle smooth. Opercle without spines. Nostrils round, paired, positioned close together and anteroventral to eye. Anterior nostril with small flap. Mouth small, posteriormost point of upper jaw below anterior margin of eye. 5 or 6 rows of conical teeth on upper and lower jaws. Lips of NMMB-P27296 swollen.

Dorsal-fin origin located above posteriormost point of opercle, and uppermost point of pectoral-fin insertion; posterior end of dorsal-fin base located towel behind posterior end of anal fin base. Contour of spinous portion of dorsal fin moderately notched, soft ray portion almost straight. Anal-fin origin located below origin of 4-5th dorsal-fin soft ray. Origin of pelvic fin located below lowermost point of pectoral-fin insertion. Posterior margin of pectoral fin moderately pointed, reaching to a vertical line through origin of 10th dorsal-fin spine. Depressed pelvic fin beyond a vertical line through origin of last dorsal-fin spine, not reaching anus. Caudal fin triangular with rounded lobes.

Colour when fresh. Body and head brownish yellow with 8-11 black-edged white longitudinal stripes (8 stripes: NMMB-P26733, 212.6 mm SL; 9 stripes: NMMB-P26732, $283.1 \mathrm{~mm}$ SL; 11 stripes: NMMB-P 27296, $344.3 \mathrm{~mm}$ SL); 4-5 stripes through caudal peduncle; all fins bright yellow; faint brown spots on anterior half of caudal fin of NMMB-P26733; vermiculated white stripes on caudal fin of NMMB-P27296; iris yellow; upper lip yellow; lower lip white; tongue and gill rakers scarlet.

Distribution. Plectorhinchus polytaenia is currently known mainly from the western Pacific Ocean (McKay 2001, Allen and Erdmann 2012). Specimens have previously been collected from the Indo-West Pacific, north to the Philippines, west to the western coast of India, south to Western Australia, east to the Solomon Islands (McKay 2001, Allen and Erdmann 2012), and now from Taiwan (presently reported study).

\section{DISCUSSION}

The majority of morphological characters of the presently described specimens agree well with the diagnosis of Plectorhinchus polytaenia given by McKay (2001): lips swollen in large individual (NMMB-P27296); chin naked with 6 sensory pores; total gill rakers 27-28; dorsal fin with $12-13$ spines and 21-22 rays; scales ctenoid; lateral line scales 54-56; 8-11 black-edged white longitudinal stripes on body; fins, iris and upper lip yellow; tongue and gill rakers scarlet. The difference
Table 1

Counts and measurements of specimens of Plectorhinchus polytaenia collected from Southern Taiwan

\begin{tabular}{lrrr}
\hline \multirow{2}{*}{\multicolumn{1}{c}{ Character }} & \multicolumn{3}{c}{$\begin{array}{c}\text { Specimen (number in } \\
\end{array}$} \\
\cline { 2 - 4 } & 26732 & 26733 & 26733 \\
\hline Standard length (SL) [mm] & 283.1 & 212.6 & 344.3 \\
\hline Counts & & & \\
\hline Dorsal-fin spines & 12 & 13 & 12 \\
Dorsal-fin rays & 22 & 21 & 22 \\
Anal-fin spines & 3 & 3 & 3 \\
Anal-fin rays & 7 & 7 & 7 \\
Pectoral-fin rays & 17 & 18 & 18 \\
Pelvic-fin spine & 1 & 1 & 1 \\
Pelvic-fin rays & 5 & 5 & 5 \\
Lateral-line scales & 56 & 54 & 54 \\
Transverse scales above lateral line & 14 & 15 & 14 \\
Transverse scales below lateral line & 23 & 22 & 22 \\
Gill rakers (upper) & 9 & 9 & 9 \\
Gill rakers (lower) & 18 & 19 & 19 \\
Gill rakers (total) & 27 & 28 & 28 \\
\hline
\end{tabular}

Measurements [\% of SL]

\begin{tabular}{llll}
\hline Greatest body depth & 33.8 & 36.5 & 35.1
\end{tabular}

Body width

Head length

$\begin{array}{lll}15.5 & 16.7 & 15.9\end{array}$

Snout length

Orbit diameter

Pupil diameter

Interorbital width

Suborbital depth

Preorbital width

Caudal-peduncle depth

Caudal-peduncle length

$\begin{array}{lll}29.8 & 30.7 & 30.5\end{array}$

$\begin{array}{lll}12.4 & 11.9 & 13.3\end{array}$

$\begin{array}{lll}7.6 & 8.5 & 7.0\end{array}$

$\begin{array}{lll}4.0 & 4.4 & 3.6\end{array}$

$\begin{array}{lll}9.4 & 9.3 & 10.1\end{array}$

$\begin{array}{lll}7.1 & 7.3 & 8.1\end{array}$

$\begin{array}{lll}8.3 & 8.0 & 8.7\end{array}$

$\begin{array}{lll}11.1 & 10.9 & 11.2\end{array}$

$\begin{array}{lll}22.2 & 22.4 & 21.6\end{array}$

Pre-dorsal-fin length

Pre-anal-fin length

$\begin{array}{lll}35.9 & 36.8 & 36.8\end{array}$

Pre-pelvic-fin length

$\begin{array}{lll}67.7 & 68.2 & 70.4\end{array}$

$\begin{array}{lll}35.6 & 35.7 & 36.5\end{array}$

$\begin{array}{lll}11.1 & 10.3 & 11.4\end{array}$

Upper-jaw length

First dorsal-fin spine length

Longest dorsal-fin spine length

$\begin{array}{lll}5.8 & 7.2 & 5.6\end{array}$

$\begin{array}{lll}12.1 & 13.4 & 11.9\end{array}$

$\begin{array}{lll}12.6 & 15.3 & 13.4\end{array}$

$\begin{array}{llll}\text { Spinous dorsal-fin base length } & 29.0 & 30.8 & 28.9\end{array}$

$\begin{array}{llll}\text { Soft dorsal-fin base length } & 30.7 & 30.4 & 31.7\end{array}$

$\begin{array}{llll}\text { First anal-fin spine length } & 4.3 & 4.8 & 3.6\end{array}$

$\begin{array}{llll}\text { Second anal-fin spine length } & 13.8 & 13.3 & 11.9\end{array}$

$\begin{array}{llll}\text { Third anal-fin spine length } & 12.3 & 12.1 & 10.5\end{array}$

$\begin{array}{llll}\text { Longest anal-fin ray length } & 16.2 & 16.6 & 16.8\end{array}$

$\begin{array}{llll}\text { Anal-fin base length } & 10.7 & 11.4 & 10.3\end{array}$

$\begin{array}{llll}\text { Caudal-fin length } & 19.5 & 21.7 & 19.0\end{array}$

$\begin{array}{llll}\text { Longest pectoral-fin ray length } & 19.1 & 20.1 & 19.6\end{array}$

$\begin{array}{llll}\text { Pelvic-fin length } & 23.0 & 19.0 & 21.9\end{array}$

\begin{tabular}{llll} 
Pelvic spine length & 13.0 & 13.6 & 12.6 \\
\hline
\end{tabular} 
of number of longitudinal stripes on body may reflect the growth coloration change of this species.

Although Plectorhinchus polytaenia has quite a unique characteristic colour in the genus, the species is most similar to Plectorhinchus lineatus (Linnaeus, 1758) and Plectorhinchus vittatus (Linnaeus, 1758) in having more than 4 white stripes on body and all fins yellowish (Fig. 2). Plectorhinchus polytaenia has many white horizontal stripes with blackish margins and alternating yellow stripes on lateral side of body, whereas there are only alternating black and white horizontal stripes in P. vittatus; and alternating black and white oblique stripes on the upper part of the body and no stripe on the lower part of the body in $P$. lineatus. The pectoral-fin base has a large red blotch in $P$. lineatus, which is absent in P. polytaenia and $P$. vittatus. All fins are uniformly bright yellow, whereas $P$. lineatus and $P$. vittatus have many black spots on the dorsal, anal, and caudal fins (McKay 2001, Allen and Erdmann 2012).
Plectorhinchus polytaenia has not been previously recorded from Taiwanese waters, and the northernmost record of the species was hitherto from Philippines (McKay 2001, Allen and Erdmann 2012). The presently described specimens collected from southern Taiwan thus represents the first record of $P$. polytaenia from Taiwan, and constitute the northernmost record of the species.

\section{ACKNOWLEDGEMENTS}

We are very grateful to Hiroyuki Motomura (KAUM) for the opportunity to examine photographs of the genus Plectorhinchus. We also thank Mr. JianTing Lin, Mr. Jian-Fu Huang, and Mrs. Ayumi Koeda (NMMB-P) for curatorial assistance. The presently reported study was supported in part by a Japan Society for the Promotion of Science, Overseas Research Fellowships (29-304) to the first author.

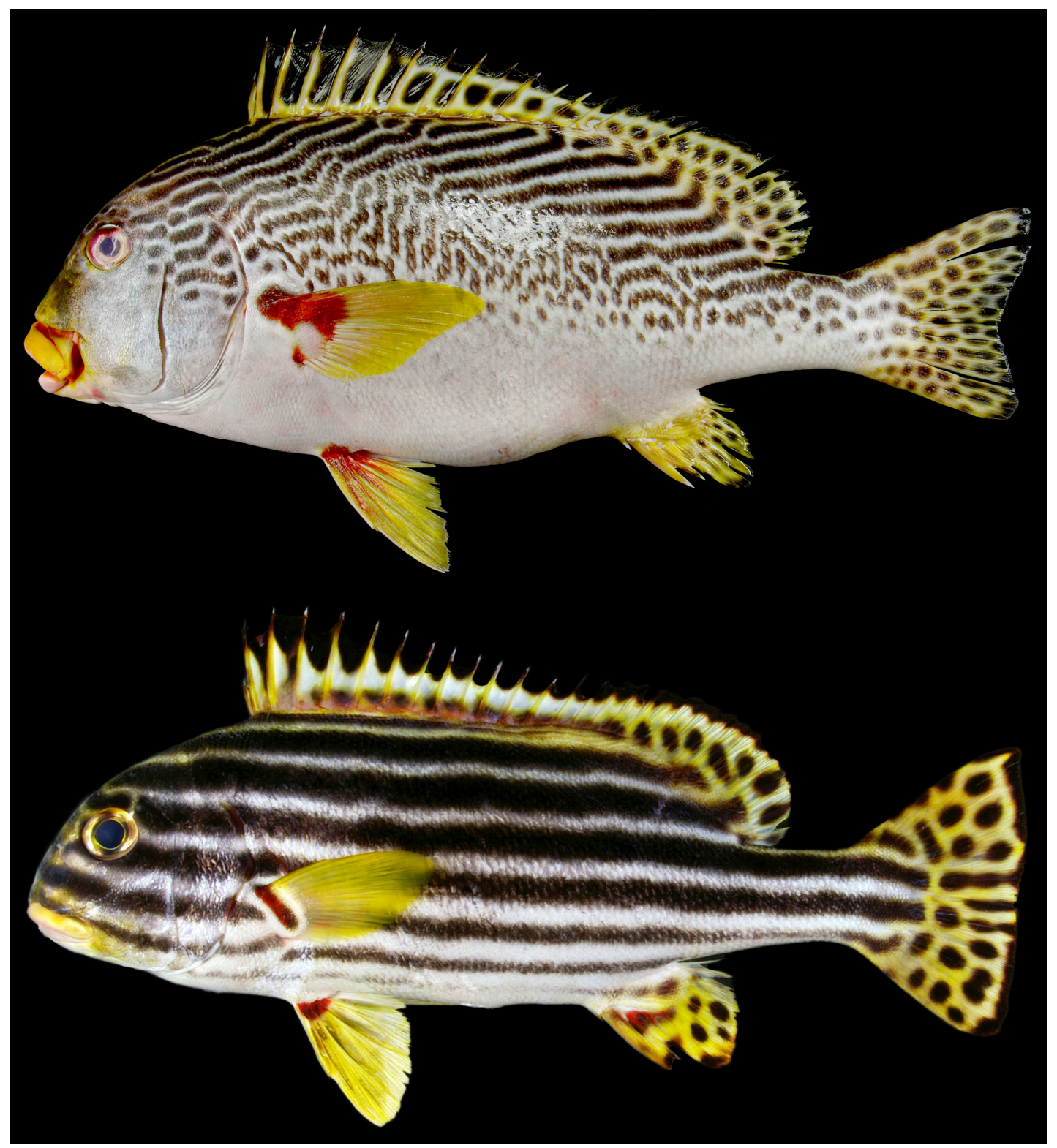

Fig. 2. Fresh specimens of genus Plectorhinchus. Upper: P. lineatus, KAUM-I. 82708, 446.0 mm standard length (SL), Tanega-shima Island, Japan; Lower: P. vittatus, KAUM-I. 30167, 273.5 mm SL, Uchinoura Bay, Kagoshima, Japan 


\section{REFERENCES}

Allen G.R., Erdmann M.V. 2012. Reef fishes of the East Indies. Volumes 1-3. Tropical Reef Research, Perth, Australia.

Larson H.K., Williams R.S., Hammer M.P. 2013. An annotated checklist of the fishes of the Northern Territory, Australia. Zootaxa 3696 (1): 1-293. DOI: 10.11646/zootaxa.3696.1.1

McKay R.J. 2001. Haemulidae. Pp. 2961-2989, pls. XIII-XV. In: Carpenter K.E., Niem V.H. (eds.) FAO species identification guide for fishery purposes. The living marine resources of the western central Pacific. Volume 5: Bony fishes part 3 (Menidae to Pomacentridae). FAO, Rome.
Randall J.E., Lim K.K.P. (eds.) 2000. A checklist of the fishes of the South China Sea. The Raffles Bulletin of Zoology 8 (Suppl. 8): 569-677.

Satapoomin U., Randall J. E. 2000. Plectorhinchus macrospilus, a new species of thicklip (Perciformes: Haemulidae) from the Andaman Sea off southwestern Thailand. Phuket Marine Biological Center Research Bulletin 63: 9-16.

Shen S.-C., Wu K.-Y. 2011. [Fishes of Taiwan.] National Museum of Marine Biology and Aquarium, Checheng, Taiwan. [In Chinese.]

Received: 17 January 2018

Accepted: 26 April 2018

Published electronically: 30 September 2018 